\title{
THE WHOLE PLANT RECONSTRUCTION OF BANISTERIAECARPUM GIGANTEUM AND BYTTNERIOPHYLLUM TILIIFOLIUM - A PRELIMINARY REPORT
}

\author{
Zlatko Kvaček $^{1^{*}}$ \& Lilla Hably ${ }^{2}$ \\ $1^{*}$ Charles University in Prague, Faculty of Science, Institute of Geology and Palaeontology, Albertov 6, CZ 12843 Praha 2, \\ Czech Republic; e-mail kvacek@natur.cuni.cz \\ ${ }^{2}$ Hungarian Natural History Museum, Botanical Department, H-1476 Budapest, Pf. 222, Hungary; hably@bot.nhmus.hu
}

Key words: Fossil Malvaceae; Europe; middle Miocene to Pliocene; fruits; foliage

\begin{abstract}
New records of fruits of Banisteriaecarpum giganteum (Göppert) Kräusel from the middle and late Miocene of Austria and Hungary and the Pliocene of Romania regularly associated with foliage of Byttneriophyllum tiliifolium (A. Braun) Knobloch \& Kvaček confirm previous views of Czeczott, Ticleanu and others that the two organs belong to a single plant related to Malvaceae s.l. and not to Mapighiaceae, as previously assumed by Schenk, Kräusel and Kirchheimer. According to the fruit morphology it is closely similar to Tarrietia Blume (tropical SE Asia and Africa, sometimes included together with Argyrodendron F. Muel. to Heritiera Dryand. in Ait.), with which it partly shares habitats (swamp to riparian forests) and decidedly differs in foliage (leaves strongly asymmetric ovate vs symmetric simple ovate to elongate or palmately compound) and climatic requirements (warm temperate vs tropical conditions). Its pollen has not yet been firmly discriminated. The fossils so far assigned to Tarrietia from Europe must be excluded from this genus: Tarrietia hungarica Rásky from the early Oligocene of Hungary was assumed by Andreánszky as legume fruits (Machaerites hungaricus (Rásky) Andreánszky), Tarrietia germanica Rüffle from the early Miocene of Germany, according to fine venation pattern, may also represent a monospermic legume pod.
\end{abstract}

\section{INTRODUCTION}

The whole plant concept in palaeobotany has lately attracted much interest of those working mainly with megafossil remains of various ages (see e.g. Kvaček, 2005, 2008). Until we are able to recognize individual whole plants in the fossil record we can hardly fully understand diversity of ancient plant world and the significance of plant elements for palaeoenvironmental reconstructions.

In this preliminary paper we bring one example of the whole plant concept represented by the "giant maple" Banisteriaecarpum giganteum (Göppert) Kräusel, a characteristic extinct plant element of the Cenozoic of Eurasia and discuss its systematic affinities and nomenclature. Our report precedes a wider revision requiring inspection of more records from Eurasia. This research was initiated by late Nicolae Ticleanu, former professor of the University of Bucharest, who collected with other Romanian explorers (Tुicleanu, 1982) most complete series of the fruits treated in this paper and invited us to cooperate, but was unable to fin- ish our study. Independently from this study, a wider monograph on the malvalean Neogene foliage and co-occurring pollen was published in cooperation with Grzegorz and ElżbietaWorobiec, Kraków (Worobiec et al., 2010) and another monograph of the late Miocene flora of Hungary containing Banisteriaecarpum (Hably, 2013).

\section{MATERIAL AND METHODS}

The studied material of Banisteriaecarpum giganteum includes either fruit impressions without traces of lignified matter preserved in sandy or silty oxidized layers (Hungarian Pannonian of Rudabánya-Vilmos, Austrian middle Miocene of Graz-Andritz - see Hably, 2013) or, more importantly, compressions with preserved lignified tissue allowing epidermal studies (Romanian Pliocene of Bălteni, Lupoaia - see Ţicleanu, 1989). The co-occurring fossil foliage of Byttneriophyllum tiliifolium is similar in its preservation mode, i.e. both 
impressions and lignified compressions. Preliminary attempts to macerate pericarp tissue of the fruits (Schulze's solution in combination with $10 \%$ $\mathrm{KOH}$ ) yielded only poorly preserved structures and require further preparations. The compression foliage of Byttneriophyllum from the Romanian Pliocene has not yet been studied for cuticles. The co-occurring pollen at Rudabánya and Lupoaia was explored separately earlier (E. Worobiec in Worobiec et al., 2010). Most of the studied fossil material is housed in the Hungarian Geological and Geophysical Institute, Budapest (BK), Hungarian Natural History Museum, Budapest (BP), University of Bucharest (UBUC), Institut für Botanik, Karl-Franzens-Universität in Graz, (UGR) and Landesmuseum Joanneum, Graz (JOAN).

We devote much attention to comparisons with possible living relatives, which we studied in several herbaria, i.e. Hungarian Natural History Museum, Budapest (BP), Muséum d'Histoire naturelle, Paris (P), Charles University in Prague (PRC) and in the field in Hainan.

\section{RESULTS}

\section{Previous views}

These maple-like fruits were originally described by Göppert (1852) from the Polish Neogene limestone at Stróza (in German Striese). Göppert named them as Acer giganteum Göppert (1852, p. 279 , pl. 38, figs 1a-c, 2, 3). Because of the large size of fruits he considered a connection with associated foliage not fitting into any species of maple and assigned the foliage to Dombeyopsis Unger. In the same work Göppert named a smaller specimen of fruits as Acer otopteris Göppert (1852, p. 279, pl. 38, fig. 4). For the latter he believed to belong to a maple but he also admitted that such fruits are similar to winged fruits of the Malpighiaceae, namely Heteropterys chrysophylla (Lamarck) Kunth. Later Unger (1856, pp. 29-30) assumed that such single-seeded fruits from Austrian middle Miocene at Prävali may partly represent pods of legumes of Centrolobium Martius ex Bentham and named them Centrolobium giganteum (Göppert) Unger. Schenk (1890) directly interpreted these fossils to belong to disintegrated fruits of the Malpighiaceae Juss., namely the genus Banisteria L. (now a synonym of Heteropterys H.B.K., nom. cons. and Banisteriopsis C.B. Rob. \& Small) from American tropics. Kräusel (1951) summarized all previous views and preferred to establish for fruits a fossil genus Banisteriaecarpum of the Malpighiaceae because in his opinion it would be difficult to decide, to which genus of this family the fruits really belong. This concept was also accepted by Kirchheimer who lists most of the so far known records (Kirchheimer, 1957, pp. 82, 652).

Czeczott (1967) stated differences between fruits of Banisteriaecarpum and Banisteria and noted regular co-occurrence of Banisteriaecarpum with strongly asymmetric leaves of "Ficus" tiliaefolia (A. Braun) Heer (= Byttneriophyllum tiliifolium (A. Braun) Knobloch \& Kvaček). She was the first who questioned affinities to Mapighiaceae and suggested possible relationship to Sterculiaceae (DC.) Bartl. (= Malvaceae Juss. subfam. Sterculioideae Beilschm.).

Ticleanu (1982) recovered with other colleagues the most complete collection of Banisteriaecarpum fruits in the Romanian Pliocene. Endeavoring the whole plant designation, he later (Tुicleanu, 1989) created a parallel new name combination Byttneriophyllum giganteum (Göppert) Ticleanu, besides Byttneriophyllum tiliifolium, in order to unite the two organs into a single fossil genus with two species. This solution has not been followed (Hably \& Kovar-Eder, 1996; Hably 2013) and is not in line with current nomenclatural rules (see below).

\section{Nomenclature}

Two fossil genera have been used for naming disconnected fruits and foliage: Banisteriaecarpum Kräusel (1951) typified by B. giganteum (Göppert) Kräusel and Byttneriophyllum Givulescu ex Knobloch \& Kvaček (1965a, b) typified by Byttneriophyllum tiliifolium (A. Braun) Knobloch \& Kvaček. The latter was superfluously replaced by Braunia Givulescu (1970) - see Jähnichen (1984). Hence the combination Braunia tiliaefolia (A. Braun) Givulescu is illegitime and cannot be employed for both fruits and foliage, as proposed by Ticleanu (1982). Also it is not in line of the nomenclatural code to accept the combination Byttneriophyllum giganteum (Göppert) Ticleanu (1989) because Banisteriaecarpum was published earlier (Kräusel, 1951) than Byttneriophyllum Givulescu ex Knobloch \& Kvaček 1965a and should be given priority.

Banisteriaecarpum papilio Andreánszky (1955, p. 43, fig. 4) from the Hungarian Oligocene should be removed from this fossil genus because it clearly deviates from the concept suggested by Kräusel (1951) and requires a separate detailed revision. 


\section{Plate I.}
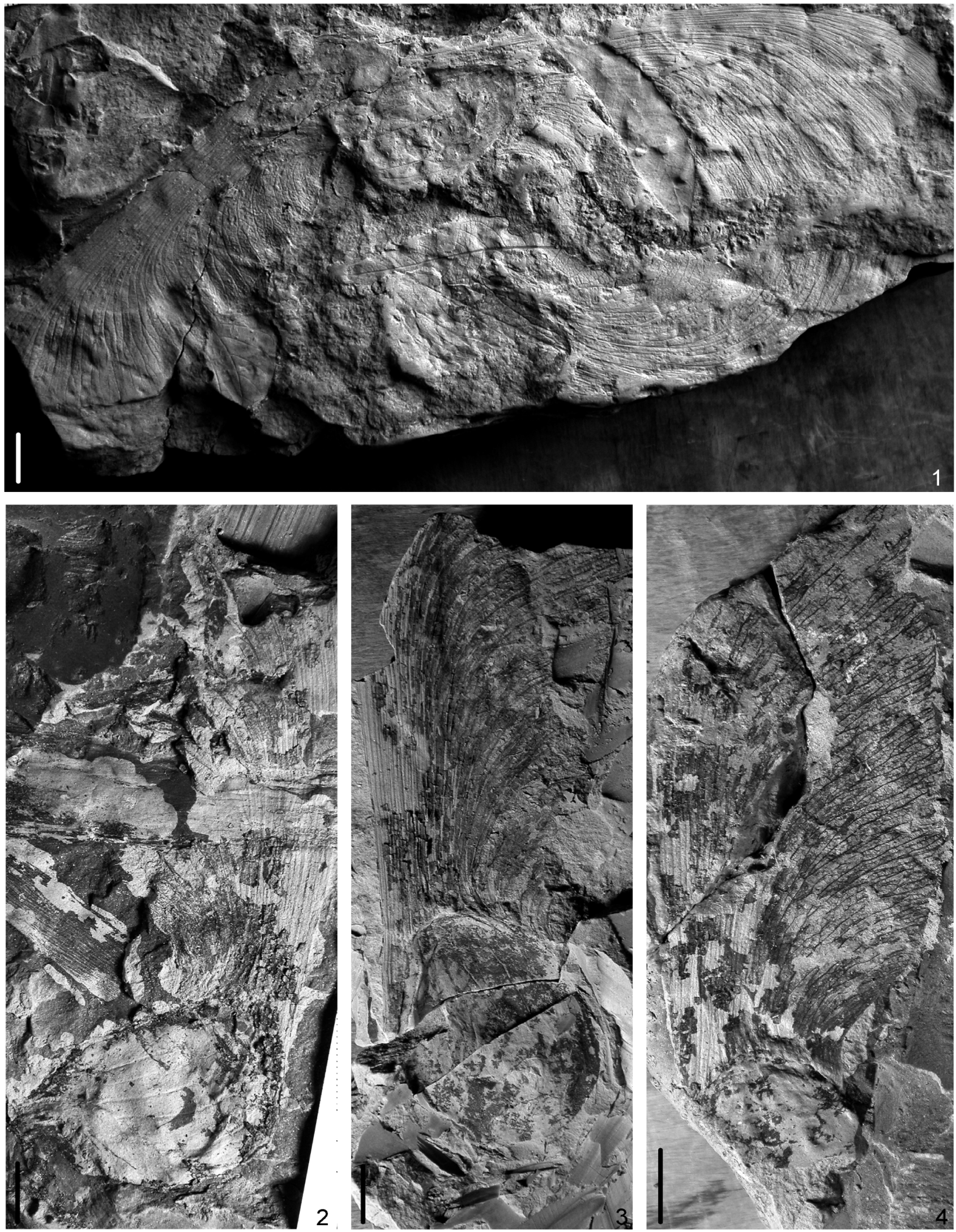


\section{Plate II.}
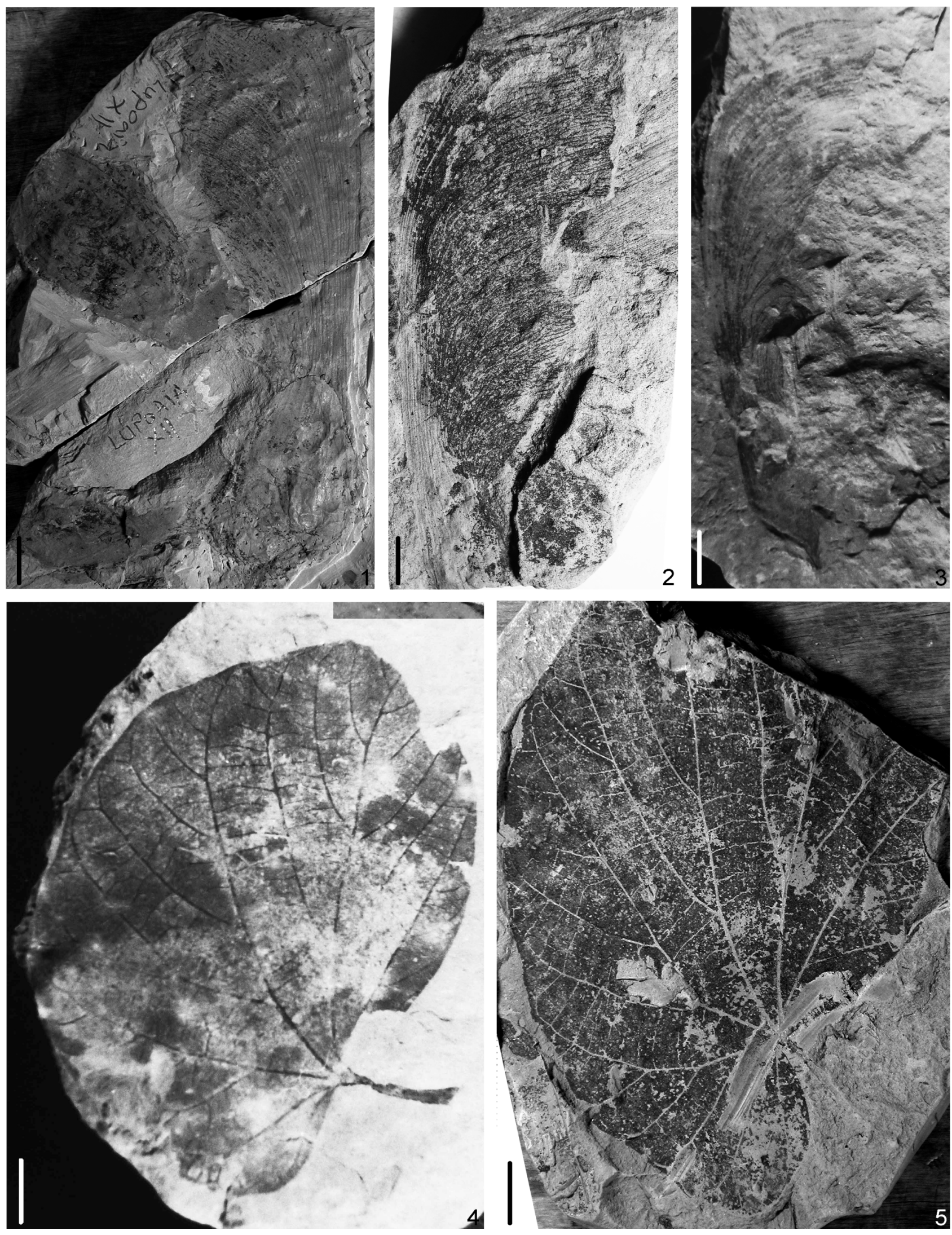


\section{PROPOSED INTERPRETATION OF THE BANISTERIAECARPUM GIGANTEUM - BYTTNERIOPHYLLUM TILIIFOLIUM PLANT}

\section{Fruits}

New records of fruits of Banisteriaecarpum giganteum (Plate I, figs 1-4; Plate II, figs 1-3) from the middle and late Miocene of Austria and Hungary (Hably, 2013) and the Pliocene of Romania (Ticleanu, 1982) were found regularly associated with the foliage of Byttneriophyllum tiliifolium (Plate II figs 4-5). Thus they confirm previous views of Czeczott (1967), Ticleanu (1989) and others that the two organs belong to a single plant related to Malvaceaes s.l. and not to Mapighiaceae, as assumed by Schenk (1890), Kräusel (1951) and Kirchheimer (1957).

According to the fruit morphology this plant is closely similar to Tarrietia Blume (Pl. 3, figs 7-9) distributed in tropical SE Asia, sometimes merged with Heritiera Dryand. in Ait. together with Argyrodendron F. Muell. (Kostermans, 1959), with which it partly shares habitats (swamp to riparian forests) and decidedly differs in foliage (leaves strongly asymmetric ovate vs symmetric ovateelongate, simple or palmately compound) and climatic requirements (warm temperate vs tropical conditions).

More detailed study will be accomplished in the future, but first attempts to get epidermal pericarp structure of Banisteriaecarpum fruits are promising showing some important features, such as bases of stellate trichomes on the surface. Fossils referred to Banisteriaecarpum giganteum from East Asia (Fotjanova, 1988; Ozaki, 1991; Chen Yun-fa, personal communication 2014) require also further studies.

\section{Foliage}

First descriptions of foliage which we assume to belong to Banisteriaecarpum, were published as Cordia tiliifolia A. Braun (1845, p. 170) from the middle Miocene of Öhningen. Göppert (1852) assigned such leaf fossils co-occurring with his Acer giganteum to the fossil genus Dombeyopsis Unger under three species D. tiliifolia (A. Braun) Unger, D. grandifolia Unger and D. aequalifolia Göppert. Different views on affinities of this peculiar morphotype stems from an unusual asymmetric form of the leaf lamina and venation. The epidermal study by Knobloch and Kvaček (1965a, b) denied its inclusions into the genera Cordia (Braun 1845), Ficus (Heer, 1856), Alangium (Kryshtofowich, 1937; Iljinskaya, 1968) and suggested most acceptable solution to treat it in a separate fossil genus Byttneriophyllum following the concept proposed by Givulescu (1959). A more thorough epidermal study (Worobiec et al., 2010) summarized previous interpretations and confirmed this concept treating Byttneriophyllum foliage as a part of the plant bearing Banisteriaecarpum fruits.

\section{Pollen}

Connection with the dispersed pollen has not been resolved so far. Worobiec et al. (2010) attempted to fix the relationship of various malvalean morphotypes used for foliage (Dombeyopsis lobata Unger, Byttneriophyllum tiliifolium (A. Braun) Knobloch \& Kvaček, "Ficus" truncata Heer) with dispersed pollen types and sampled layers, where foliage of Byttneriophyllum tiliifolium abundantly occurred. In samples from Rudabánya and Lupoaia, where even fruits of Banisteriaecarpum are present, single specimens of Intratriporopollenites insculptus Mai were encountered while at Belchatów in asso-

Plate I, figs 1-4. Banisteriaecarpum giganteum (Göppert) Kräusel; 1) A group of detached fruits, Lupoaia, Pliocene, NT-L281b (UBUC), scale bar $10 \mathrm{~mm}$; 2) Seed part with curved neck and distinct venation of wing. Lupoaia, Pliocene, NT-L278(2) (UBUC), scale bar $10 \mathrm{~mm}$; 3) Seed part with carbonized pericarp. Lupoaia, Pliocene, NT-L279 (UBUC), scale bar $10 \mathrm{~mm}$; 4) Incomplete fruit with distinct venation of wing. Bălteni, Pliocene, NT-L282 (UBUC), scale bar $10 \mathrm{~mm}$.

Plate II, figs 1-3. Banisteriaecarpum giganteum (Göppert) Kräusel; 1) A group of big fruits, Lupoaia, Pliocene, NT-L280 (UBUC), scale bar $10 \mathrm{~mm}$; 2) Almost complete fruit, Rudabánya, late Miocene, BK 554 (BK), scale bar $10 \mathrm{~mm}$; 3) A complete fruit with straight neck, Graz-Andritz, middle Miocene, Pb 17.10 (UGR), scale bar 10 mm; figs 4-5. Byttneriophyllum tiliifolium (A. Braun) Knobloch \& Kvaček; 4) Petiolate leaf impression, Graz-Andritz, middle Miocene, Pb 17.10 (UGR), scale bar $10 \mathrm{~mm}$; 5) Carbonized compression, Lupoaia, Pliocene, NT-L283 (UBUC), scale bar $10 \mathrm{~mm}$. 
ciation of Byttneriophyllum foliage the pollen of the Intratriporopollenites instructus type occurred. E. Worobiec (in Worobiec et al., 2010, p. 910) stated: "For the fossil leaf morphogenus Byttneriophyllum, an appropriate pollen type has not been discriminated, but pollen grains of $I$. instructus often accompanied these leaves." Fossil flowers in association with the Banisteriaecarpum - Byttneriophyllum plant have not been recovered so far even in the sub-autochthonous assemblages. Krutzsch (2004) treated in detail the above-mentioned "tilioid" pollen taxa but unfortunately left aside comparisons with pollen of the Sterculioideae.

\section{Affinities to modern angiosperms}

Maple-like winged fruits are produced in various groups of eudicots (Kirchheimer, 1957, p. 34). Indeed, disintegrated double samaras of Acer (Plate III, figs 1-2) and the Malpighiaceae (Plate III, figs 3-5) may look similar to Banisteriaecarpum. On account of foliage and its epidermal micromorphology the Banisteriaecarpum - Byttneriophyllum plant must be related to the Malvaceae s.l. (Knobloch \& Kvaček, 1965a, b; Worobiec et al., 2010). Anomocytic stomata, stellate trichomes and glandular multicellular clavate trichomes suggest affinities with the subfamilies Tilioideae Arn. or Brownlowioideae Burret (G. Worobiec in Worobiec et al., 2010) while the fruit morphology is leading to the Sterculioideae Beilschm. (Czeczott, 1967; Ticleanu, 1982, 1989). The complete samara of Heritiera (Plate III, fig. 6) differs considerably by its globose form but the winged fruits of Tarrietia match Banisteriaecarpum in many respects (Plate III, figs 7-9). However, we did not find any living relative producing similar foliage (cf. Plate III, figs 10-12). In our opinion it is necessary to recognize other organs, namely dispersed pollen, and carry out detailed palynological studies in order to resolve exact position of the Banisteriaecarpum Byttneriophyllum plant within the Malvaceae s.l. Also a recovery of wood, possibly belonging to this extinct element, would be of great importance.

\section{FOSSILS EXCLUDED FROM THE MALVACEAE S.L.}

Rásky (1950) described a winged disseminule from the early Oligocene of Hungary (locality Budaújlak), which she interpreted as a samara of Tarrietia (T. hungarica Rásky) (Plate IV, fig. 1). Some other specimens collected from the same site (Plate IV, figs 2-5) were assumed by Andreánszky (1962, p. 228, 1965, p. 67) as legume fruits (Machaerites hungaricus (Rásky) Andreánszky). According to S.R Manchester (personal communication 2014), also seeds of some Anacardiaceae (Schinopsis Engl.) are comparable.

A fruit interpreted as belonging to Tarrietia was described from the early Miocene of the Randeck Maar, Germany as Tarrietia germanica Rüffle (1963, p. 247, pl. 14. fig. 17 , pl. 27, fig. 8). We observed on the holotype fine venation pattern characteristic of legume pods (Plate IV, fig. 6) proving that this fossil may represent a legume fruit and not that of Tarrietia nor Koelreuteria Laxmann, as Gregor (1986, p. 11) suggested.

\section{CONCLUSIONS}

New records of fruits of Banisteriaecarpum giganteum accompanied by foliage of Byttneriophyllum tiliifolium from the Miocene of Austria, Hungary and the Pliocene of Romania confirm previous views of Czeczott (1967), Ticleanu (1982, 1989), Worobiec et al. (2010), Hably (2013) and others that the two organs belong to a single plant related to Malvaceae s.l. and not to Mapighiaceae.

The Banisteriaecarpum giganteum - Byttneriophyllum tiliifolium plant is closely similar in fruits to Tarrietia Blume (mainly tropics in SE Asia) with which it shares partly also similar habitats (swamp to riparian forests) but decidedly differs in foliage and climatic requirements (warm temperate vs tropical conditions).

Fossils assigned to Banisteriaecarpum giganteum and associated with foliage similar to Byttneriophyllum tiliifolium were also recorded from the Cenozoic of East Asia, e.g. Sakhalin (Fotjanova, 1988), Japan (Ozaki, 1991) and China (Chen Yunfa, personal communication). The relevant material was only partly accessible for the present account and requires further studies.

Fossil fruits so far assigned to Tarrietia from Europe must be excluded from this genus probably representing legume pods. 

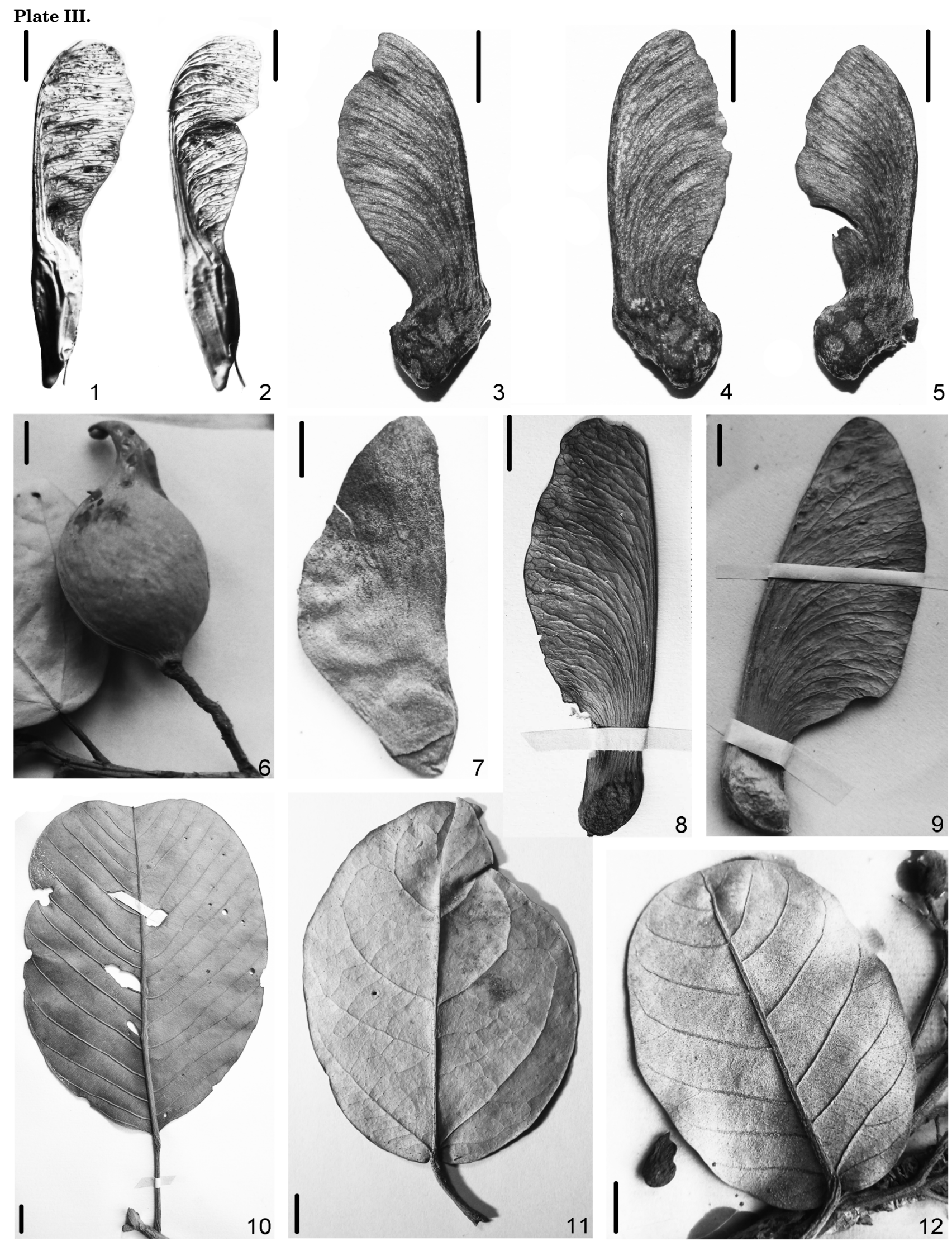

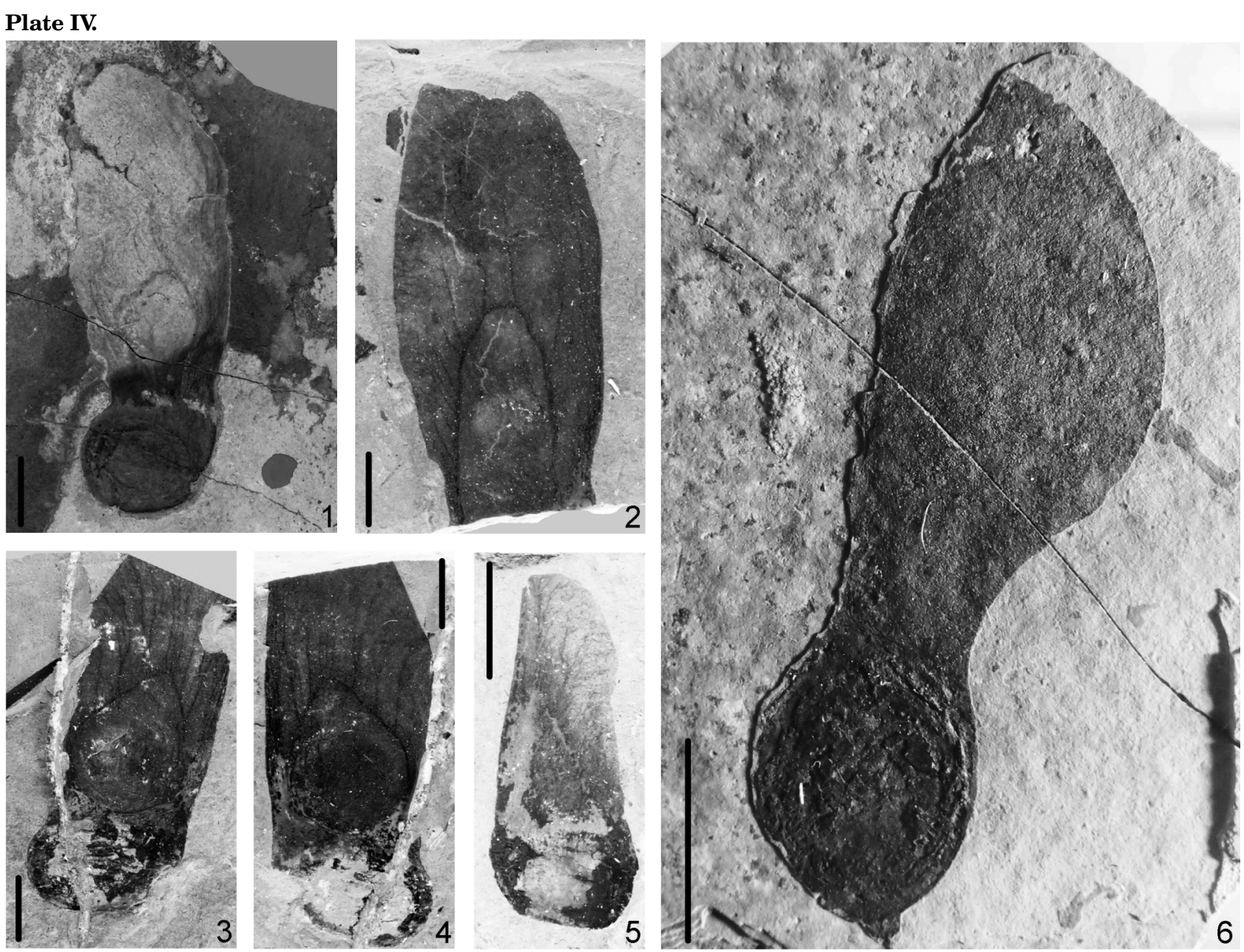

Plate IV, figs 1-5. "Tarrietia" hungarica Rásky (=Machaerites hungaricus (Rásky) Andreánszky), Budaújlak, early Oligocene of Hungary; 1) Type specimen, BP 55.2199.2, scale bar10 mm; 2) Incomplete fruit showing venation, BP 55.2200.1, scale bar $10 \mathrm{~mm}$; 3) Fruit with seed part, BP 56.2197.2, scale bar $10 \mathrm{~mm}$; 4) Counter-impression of the previous specimen, BP 56.2197.2, scale bar $10 \mathrm{~mm}$; 5) Small fruit, BP 55.2198.2, scale bar $10 \mathrm{~mm}$; 6) "Tarrietia" germanica Rüffle, holotype, Randeck Maar, middle Miocene, P 1224/588, Staatliches Museum für Naturkunde, Stuttgart, scale bar 10 mm.

Plate III, figs 1-2. Acer negundo L., separate parts of double samara, cult. Praha-Bohnice, scale bars 5 mm; 3-5. Heteropterys bellonis Urb., separate parts of double samaras, Porto Rico, Sabaun Grande, Sintenis 3892 (PB), scale bars 5 mm; 6 ) Heritiera percoriacea Kosterm., globular fruit, SW Java, Udhung Kulon, Kostermans 14100 (P), scale bar 5 mm, 7) Tarrietia parvifolia (Merr.) Merr.\& Chun, small winged fruit, Hainan, Yaichow, How 71047 (P), scale bar 5 mm; 8) Tarrietia symplicifolia Mast., winged fruit, N. Borneo, Enggoh 7138 (P), scale bar $10 \mathrm{~mm}$; 9) Tarrietia javanica Blume, winged fruit, Cambodia, Bijeaud sine num. (P), scale bar $10 \mathrm{~mm}$; 10) Tarrietia symplicifolia Mast., leaf, N. Borneo, Enggoh 7138 (P), scale bar $10 \mathrm{~mm}$; 11) Heritiera cordata Kosterm., leaf, Annam, Poilane 4950 (P), scale bar $10 \mathrm{~mm}$; 12) Tarrietia parvifolia (Merr.) Merr.\& Chun, leaf, Hainan, Dongzhai Gang, Kvaček Z. sine num. March 6, 2009 (PRC), scale bar10 mm. 


\section{ACKNOWLEDGMENTS}

This study is a continuation of our research of Tertiary floras, in which we cooperated with many colleagues in Europe since long. It is most unfortunate that the initiator of this project, prof. Nicolae Tुicleanu, University of Bucharest, died before the project was completed. We thank G. and E. Worobiec, Kraków for cooperation in epidermal and pollen studies. We owe sincere thanks to a number of people and institutions for giving us opportunity to study the relevant fossil as well modern material: J. Kovar-Eder, Staatliches Museum für Naturkunde, Stuttgart, V. Parashiv, University of Bucharest, I. Rácz, Hungarian Natural History Museum, Budapest and curators of the herbaria in the Museum d' Histoire naturelle, Paris, Faculty of Science of Charles University, Prague and of the collections of the Landesmueum Joanneum, Graz, and the Botanical Institute of the Graz University for assistance; Prof. Li Cheng-sen, Beijing, guided the first author to a field trip in Hainan; Barbara Mohr, Berlin kindly accepted our report as a lecture to the program of the 23rd International Workshop on Plant Taphnonomy, Berlin, Nov. 27-28, 2014. Steven R. Manchester, Florida Museum, Gainesville corrected the manuscript linguistically, Vasilis Teodoridis critically reviewed the text and helped with illustrations. The research was carried out and financially supported by the Ministry of Education, Youth and Sports of the Czech Republic (project No. PRVOUK P 44), the Grant Agency of the Czech Republic (GA ČR project No.14-23108S) and Hungarian Scientific Research Fund (OTKA 108664).

\section{REFERENCES}

Andreánszky, G. 1955. Neue und interessante tertiäre Pflanzen aus Ungarn. Annales Hisoriconaturales Musei Nationalis Hungarici, pars mineralogica et palaeontologica 6, 37-50.

Andreánszky, G. 1962. Contributions à la connaisance de la flore de l'Oligocène supérieur de la briqueterie Wind près d'Eger (Hongrie septentrionale). Acta botanica academiae scientiarum Hungaricae 8 (3-4), 219-239.

Andreászky, G. 1965. Neue und interessante tertiäre Pflanzen aus Ungarn. IV. Annales Hisorico-naturales Musei Nationalis Hungarici, pars mineralogica et palaeontologica 57, 53-73.
Braun, A. 1845. Die tertiäre Flora von Öhningen. Neues Jahrbuch für Mineralogie, Geognosie und Geologie 1845, 164-173.

Czeczott, H. 1967. Flora kopalna Turowa koło Bogatyni. II. Systematyczny opis szczątków roślinnych (3). Sterculiaceae. Prace Muzeum Ziemi 10, 115-122, 152-156.

Fotyanova, L.I. 1988. Flora of the Far East on the Paleogene and Neogene boundary (Flora Dal'nego Vostoka na rubezhe Paleogena i Neogena). 191 pp. Nauka, Moscow. (In Russian.)

Givulescu, R. 1959. Einige Bemerkungen über die Taxonomie von Ficus tiliaefolia (Al. Br.) Heer. Neues Jahrbuch für Geologie und Paläontologie Monatshefte 1959 (10), 437-442.

Givulescu, R. 1970. Observatons nouvelles sur Byttneriophyllum tiliaefolium (Al. Br.) Knobloch $\&$ Kvaček. Review of Palaeobotany and Palynology 10, 233-243.

Göppert, H.R. 1852. Beiträge zur Tertiärflora Schlesien's. Palaeontographica 2, 258-285.

Gregor H.-J. 1986. Zur Flora des Randecker Maares (Miozän, Baden-Württemberg). Stuttgarter Beiträge zur Naturkunde, Series B (Geologie und Paläontologie) 122, 1-29.

Hably L. 2013. The Late Miocene flora of Hungary. Geologica hungarica, ser. Palaeont. 50, 1-175.

Hably, L., Kovar-Eder, J. 1996. A representative leaf assemblage of the Pannonian Lake from Dozmat near Szombathely (Westerm Hungary), Upper Pannonian, Upper Miocene. Advances in Austrian-Hungarian Joint Geological Research, Budapest, pp. 69-81.

Heer, O. 1856. Flora tertiaria helvetiae II. 110 pp. J. Wuster, Winterthur,

Iljinskaya, I. A. 1968. Neogene floras of the transcarpatian region of the USSR (Neogenovye flory zakarpatskoi oblasti SSSR). 122 pp. Nauka, Leningrad (in Russian).

Jähnichen, H. 1984. Comment on Nomenclature: "Braunia" tiliaefolia (Al. Br.) Givulescu (1970) versus Byttneriophyllum tiliaefolium (Al. Br.) Knobloch \& Kvacek (1965a). Tertiary research 6(3), 107-108.

Kirchheimer, F. 1957. Die Laubgewächse der Braunkohlenzeit. 783 pp. VEB Wilhelm Knapp Verlag, Halle (Saale).

Knobloch, E., Kvaček, Z. 1965a. Einige neue Erkenntnisse über "Ficus" tiliaefolia (Al. Braun) Heer. Neues Jahrbuch für Geologie und Paläontologie Abhandlungen 121, 201-208. 
Knobloch, E., Kvaček, Z. (1965b) Byttneriophyllum tiliaefolium (Al. Braun) Knobloch et Kvaček in den tertiären Floren der Nordhalbkugel. Sborník geologických věd, paleontologie. P.5, 123-166.

Kostermans, A.J.G.H. 1959. A monograph of the genus Heritiera Aiton (Stercul.) (including Argyrodendron F. v. M. und Tarrietia Bl.). Reinwardtia 4, 465-583.

Kräusel, R. 1951. Die tertiäre "Riesenahorn" Banisteriaecarpum nov. gen. Abhandlungen der senckenbergischen naturforschenden Gesellschaft 485, 75-80.

Krutzsch, W. 2004. Neue Untersuchungen über präquartäre Malvaceen-Pollen aus den Unterfamilien der Tilioideae, Helicteroideae und Bombacoideae. Palaeontographica Abt. B, 267, 67160.

Kryshtofowich, A. N. 1937. New data on the Tertiary flora of Novokievsk and other places of the Ussurijsk district (Novye dannye o tretichnoi flore Novokievska i drugikh mest Usuriiskogo kraia) (in Russian). Ezhegodnik Vserossiiskogo paleontologicheskogo obshchestva 11, 49-57.

Kvaček, Z. 2005. Early Miocene records of Craigia (Malvaceaes.l.) in the Most Basin, North Bohemia - whole plant approach. Journal of the Czech Geological Society 49, 161-171.

Kvaček, Z. 2008. Whole-plant reconstructions in fossil angiosperm research. International Journal of Plant Science 169(7), 918-927.

Ozaki, K. 1991. Late Miocene and Pliocene floras in Central Honshu, Japan. Bulletin of the Kanagawa Prefecture Museum of Natural Sciences, special issue, $244 \mathrm{pp}$.
Rásky, K. 1950. Tarrietia hungarica n. sp. előfordulása Magyarországon. Tarrietia hungarica n. sp. aus Ungarn. Földtani közlöny 1949, 192-194.

Rüffle L. 1963. Die obermiozäne (sarmatische) Flora von Randecker Maar. Paläontologische Abhandlungen, 1(3), 139-298.

Schenk A. 1890. Palaeophytologie. 949 pp. In: K.A. Zittel, Handbuch der Palaeontologie, II. R. Oldenbourg, München, Leipzig.

Ticleanu N. 1982. On the systematic position of Byttneriophyllum tiliaefolium (Al. Br.) Knobloch et Kvacek and Banisteriaecarpum giganteum (Goeppert) Kräusel. Dări de Seamă ale Şedințelor, Institutul de geologie Şi geofizică 66, 103-114.

Tुicleanu N. 1989. Nouvelles donnees sur la taxonomie, le habitus et l'ecologie des taxons Byttneriophyllum tiliaefolium (Al. Braun) Knobloch et Kvacek et Byttneriophyllum giganteum (Goeppert) comb. nov. Studia universitatis Babes-Bolyal geologia-geographia 34 (2), 83-87.

Unger, F. 1856. Bemerkungen über einige Pflanzenreste im Thonmergel des Kohlenflözes vom Prevali. Sitzungsberichte der Kaiserlichen Akademie der Wissenschaften, mathematischnaturwissenschaftliche Classe 18, 28-32.

Worobiec, G, Worobiec, E., Kvaček, Z. 2010. Neogene leaf morphotaxa of Malvaceaes.l. in Europe. International Journal of Plant Science 171(8), 892-914. 